\title{
膀胱癌の局所治療に関する実験的研究
}

1. 家兔移植腫瘍（ $V_{2}$ carcinoma）を用いた膀胱癌実験モデルの確立

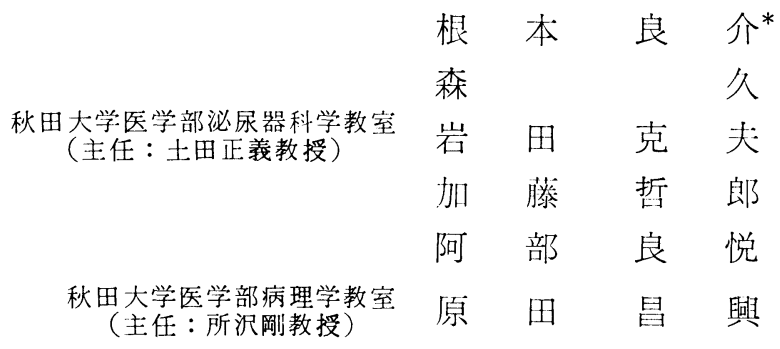

\section{EXPERIMENTAL STUDIES ON REGIONAL THERAPY OF URINARY BLADDER CANCER}

1. A Model of Urinary Bladder Carcinoma in the Rabbit Using Transplantable $\mathrm{V}_{2}$ Carcinoma

Ryosuke Nemoto, Hisashi Mori, Katsuo Iwata, Tetsuro Kato and Ryoetsu Abe

Department of Urology Akita University School of Medicine

(Directro; Prof. Seigi Tsuchida)

Masaoki Harada

Department of Pathology Akita University School of Medicine

(Director: Prof. Takeshi Shozawa)

An experimental model of bladder carcinoma was established in the rabbit using transplantable $\mathrm{V}_{2}$ carcinoma. Submucosally inoculated $\mathrm{V}_{\mathbf{2}}$ carcinoma cells were successfully transplanted into the bladder wall with an incidence of $96 \%(78 / 81)$ with the first experimental week. Significant correlation was demonstrated between the growing tumor size and inoculated tumor cell numbers. Nodullary growing submucosal tumor progressed to mucosal ulceration followed by invasive growth to the muscle layers with relatively restrictive boundary. About 4 weeks after inoculation, lymphatic metastases to the lungs were evidently observed with a high frequency. The extremely high transplantability of the tumor and short experimental periods of this model system might be advantageous for practical studies of bladder carcinoma.

要旨 : 家鬼の膀胖に同種の移植腫瘍 $\left(V_{2}\right.$ carcinoma) を用いた膀胼癌の実験モデルを確立したので報告した. 腫瘍の生着は81頭中78頭（96\%）にみられ，すべて膀胱腔内に突出し各実験群でほぼ均等な大きさであつた． 転移経路は膀胱より傍総腸骨動脈リンパ節を経て肺に至るリンパ行性転移が主体で, 転移巣の増大とともに一 部肝への血行性転移も認められた。

本実験モデルには手技が簡便なこと，腫瘍生着率が高く再現性に富むことならびに実験期間が短いこと等の 利点が指摘された。組織学的には自然発生膀胱癌とは異なるが, 增殖形態, 成育速度および転移様式が悪性腫 瘍としての条件を満しており, 膀胼癌に関する局所治療の基礎的研究に幅広い応用が期待できた.

緒言 膀腃癌の治療には膀胖の解剖学的特徵と臓器特異性を

* 現在, 筑波大学臨床医学系泌尿器科
考慮した方法がいくつか施行されている．たとえば膀胱 支配動脈である内腸骨動脈を用いた抗癌剂の動脈内注入 法” や腫瘍動脈塞栓術 ${ }^{2}$, また膀胱が管腔蔵器で経尿道 
的操作が容易なことを利用して, 抗癌剤の膀胱内注入 法 $^{3)}$ ， 水圧療法 ${ }^{4)}$ あるいは温熱療法 ${ }^{5)}$ などが施行されて いる.しかし，これら膀胼癌に対する治療法に関しては 担癌動物を用いた基礎的な研究は注とんどなく，客観的 な抗腫瘍効果の判定や抗腫瘍機序について解明すべき点 が未だに多く残されている。その最大の理由は膀胼に対 する操作が可能な大きさの動物に適当な腫瘍モデルがな かつたためと思わ机る。

今回, 著者らは家鬼の膀脱に同種の移植腫瘍 $\left(\mathrm{V}_{2}\right.$ carcinoma）を用いた膀胼癌の実験モデルを確立したので, その概要について報告する.

\section{材料および方法}

1. 家鬼: 日本白色種, 雄, 体重2.5 3kg を使用し, 市販の飼料 $\left(\mathrm{CR}_{3}\right.$, 日本クレ八) で飼育した。

2. 腫湯: 家鬼大腿部に継代した $\mathrm{V}_{2}$ carcinoma $\left(\mathrm{VX}_{2}\right.$ carcinoma と同義) を用いた。 $V_{2}$ carcinoma は1937年 Kidd \& Rous により確立された家鬼の移植悪性腫瘍で, 組織学的には扁平上皮癌に類するものとされている ${ }^{6)}$.

3. 腫瘍細胞の移植 : 家鬼大腿部より摘出した腫瘍を はさみで細切して糊状にした後, Hanks buffered saline で希釈してガーゼで 2 回濾過し，所定の 細胞密度の 細 胞浮遊液を調整した。この間,トリプシン処理は行わ ず抗生物質も添加しなかつた。腫瘍を移植する家鬼は pentobarbital $(25 \mathrm{mg} / \mathrm{kg})$ て麻酔し, 下腹部正中切開によ り開腹して膀胱を露出した後, 細胞浮遊液 $0.3 \sim 0.5 \mathrm{ml}$ を膀胱の漿膜側から壁内に注入した．細胞移植後，創を 縫合して硫酸アミカシン $5 \mathrm{mg} / \mathrm{kg}$ を筋注した。

4. 腫瘍生着率：51頭の家鬼を用いて 4 回の実験を行 なつた．各回とも所定の濃度に調整した細胞浮遊液 0.3 $\mathrm{ml}$ を膀胱壁に注入した後，一定期間をおいて屠殺して 腫湟の大きさと肺転移の有無を観察した。

5. 移植細胞数と腫瘍生着: 24 頭 の家鬼を 4 群に分 け，膀脱壁にそれぞれ $10^{3} ， 10^{4} ， 10^{5}$ ，および $10^{6}$ 個の細 胞浮遊液 $0.3 \mathrm{ml}$ を移植して, 2 週後の腫瘍の大きさを測 定した.

6. 腫場の增殖と転移: 12 頭 の 家鬼膀胼壁に $2 \times 10^{6}$ 個の細胞浮遊液 $0.5 \mathrm{ml}$ を注入した後，1週おきに 2 頭づ つ屠殺して腫瘍の大きさと形態を観察した。また肺， 肝，および傍総腸骨動脈りンパ節への転移の有無を調 ベ, 摘出臓器のホルマリン固定標本による組織学的検索 を行なつた。

なお，いずれの実験も腫場の大きさは長径 $\mathrm{X}$ 短径で表 わし，重量はホルマリン固定標本で測定した。また 5 週
目まで経過観察することができた 3 頭については，各週 毎に体重測定を行ない，腫瘍の発育と転移が家鬼の成長 に及ぼす影響を検討した。

\section{結 果}

1. 腫瘍生着率 (Table 1) : 51頭の家兔のうち腫瘍 が生着したのは49頭（96\%）で，腫瘍は全例とも膀胱腔 内に突出していた。腫場生着不成功例の 2 頭は主に初期 の実験群で, 細胞を膀脱壁に注入する際, 誤つて膀羘腔 内に細胞浮遊液を流出させたためと考兄られた。各実験 群で生着した腫瘍の大きさ（長径×短径, $\mathrm{mm}^{2}$ ) の平均

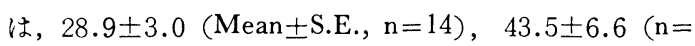
18), 67.3土8.0 ( $\mathrm{n}=10)$ および $485.1 \pm 56.3 \mathrm{~mm}^{2}(\mathrm{n}=$ 7)で各群之もほぼ一定の大きさの腫瘍を生着させること ができた．腫瘍細胞移植後 3 週間追跡した群では， 7 頭 中 6 頭に栗粒大の多発性肺転移をほぼ同程度に認めた。

2. 移植細胞数と腫瘍生着（Fig. 2) ：24頭の家鬼を 用いて，4段階の濃度に調節した細胞浮遊液を膀朕に移 植し， 2 週後の腫瘍の生着を観察した。 その結果, 細胞 数 $10^{3}$ 個を注入した群で 6 頭中 2 頭に腫瘍の生着が認め られなかつたのみで，他の群ではすべての膀胖に腫瘍 の生着をみた (Fig. 1). 生着した腫瘍の平均サイズは $10^{3}$ 群; $15.0 \pm 3.8 \mathrm{~mm}^{2}(\mathrm{n}=4), 10^{4}$ 群; $88.9 \pm 13.7 \mathrm{~mm}^{2}$ $(\mathrm{n}=6), 10^{5}$ 群; $150.8 \pm 25.9 \mathrm{~mm}^{2}(\mathrm{n}=6)$, および $10^{6}$ 群; $421.7 \pm 25.6 \mathrm{~mm}^{2}(\mathrm{n}=6)$ で各群ともほぼ均等な大 きさの腫瘍生着がみられ，とくに106群での再現性が顕 著であつた。

3. 腫瘍の增殖と転移: Table 2. は12頭の家鬼に細胞

Fig. 1 Tumor size of the urinary bladder in rabbits transplanted with various number of $\mathrm{V}_{2}$ carcinoma cells. Tumor size was caluculated using the formula, length $\mathrm{x}$ width $=\mathrm{mm}^{2}$.

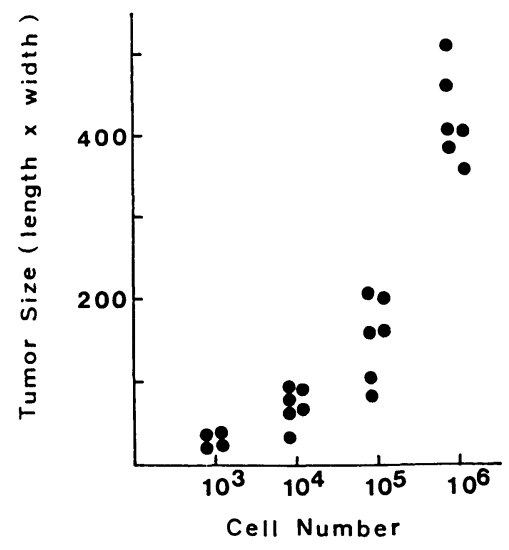


Tacble 1 Tumor frequency and reproducibility of $\mathrm{V}_{2}$ carcinoma transplanted into the urinary bladder of rabbits.

\begin{tabular}{|c|c|c|c|c|c|c|c|c|}
\hline & $\begin{array}{l}\text { Inoculated } \\
\text { Cell Number }\end{array}$ & $\begin{array}{c}\text { Period } \\
\text { (day) }\end{array}$ & (length & umor $\mathrm{Siz}$ & $\mathrm{mm})$ & $\begin{array}{c}\text { Mean Tumor Size } \\
\left(1 . \times \text { w. }, \text { mean } \pm \text { S.D. }, \mathrm{mm}^{2}\right)\end{array}$ & $\begin{array}{l}\text { Tumor } \\
\text { Frequecy } \\
(\%)\end{array}$ & $\begin{array}{l}\text { Lung } \\
\text { Metastasis }\end{array}$ \\
\hline \multirow{5}{*}{$\underset{(n=14)}{\operatorname{Exp} .1}$} & \multirow{5}{*}{$10^{6}$} & \multirow{5}{*}{7} & $8 \times 5$ & $6 \times 5$ & $5 \times 4$ & \multirow{5}{*}{$6.5 \pm 0.3 \times 5.5 \pm 0.4$} & \multirow{5}{*}{$\begin{array}{l}14 / 14 \\
(100)\end{array}$} & \multirow{5}{*}{$0 / 14$} \\
\hline & & & $7 \times 5$ & $7 \times 7$ & $7 \times 5$ & & & \\
\hline & & & $8 \times 8$ & $6 \times 5$ & $7 \times 7$ & & & \\
\hline & & & $7 \times 4$ & $8 \times 7$ & $7 \times 6$ & & & \\
\hline & & & $5 \times 4$ & $5 \times 4$ & & & & \\
\hline \multirow{6}{*}{$\begin{array}{l}\text { Exp. 2 } \\
(n=20)\end{array}$} & \multirow{6}{*}{$2 \times 10^{6}$} & \multirow{6}{*}{7} & $7 \times 6$ & $7 \times 6$ & $8 \times 6$ & \multirow{6}{*}{$7.6 \pm 0.6 \times 6.8 \pm 0.4$} & \multirow{6}{*}{$\begin{array}{l}18 / 20 \\
(90)\end{array}$} & \multirow{6}{*}{$0 / 18$} \\
\hline & & & $8 \times 7$ & $6 \times 6$ & - & & & \\
\hline & & & $5 \times 5$ & $7 \times 7$ & $10 \times 9$ & & & \\
\hline & & & $15 \times 12$ & $3 \times 3$ & $7 \times 7$ & & & \\
\hline & & & $8 \times 8$ & $7 \times 6$ & $7 \times 7$ & & & \\
\hline & & & $7 \times 7$ & $8 \times 6$ & - & & & \\
\hline \multirow{4}{*}{$\underset{(n=10)}{\operatorname{Exp} .3}$} & \multirow{4}{*}{$5 \times 10^{6}$} & \multirow{4}{*}{9} & $7 \times 7$ & $12 \times 11$ & $9 \times 9$ & \multirow{4}{*}{$9.3 \pm 0.6 \times 8.9 \pm 0.6$} & \multirow{4}{*}{$\begin{array}{l}10 / 10 \\
(100)\end{array}$} & \multirow{4}{*}{$0 / 10$} \\
\hline & & & $8 \times 7$ & $8 \times 7$ & $10 \times 10$ & & & \\
\hline & & & $9 \times 9$ & $7 \times 7$ & $11 \times 11$ & & & \\
\hline & & & $12 \times 11$ & & & & & \\
\hline \multirow{3}{*}{$\begin{array}{c}\text { Exp. } \\
(\mathrm{n}=7)\end{array}$} & \multirow{3}{*}{$10^{7}$} & \multirow{3}{*}{21} & $19 \times 17$ & $16 \times 15$ & $23 \times 22$ & \multirow{3}{*}{$22.6 \pm 1.4 \times 21.0 \times 1.4$} & \multirow{3}{*}{$\begin{array}{l}7 / 7 \\
(100)\end{array}$} & \multirow{3}{*}{$6 / 7$} \\
\hline & & & $23 \times 22$ & $25 \times 23$ & $25 \times 25$ & & & \\
\hline & & & $27 \times 23$ & & & & & \\
\hline
\end{tabular}

Table 2 Tumor growth and metastasis of $\mathrm{V}_{2}$ carcinoma transplanted into the urinary bladder of rabbits.

\begin{tabular}{|c|c|c|c|c|c|c|c|}
\hline \multirow{2}{*}{$\begin{array}{r}\text { Period } \\
\text { (week) }\end{array}$} & \multirow{2}{*}{$\begin{array}{c}\text { Tumor Size } \\
\left(\text { length } \times \text { width }, \mathrm{mm}^{2}\right)\end{array}$} & \multirow{2}{*}{$\begin{array}{c}\text { Tumor Weight } \\
(\mathrm{g})\end{array}$} & \multirow[b]{2}{*}{ Ulceration } & \multirow{2}{*}{$\begin{array}{l}\text { Central } \\
\text { Necrosis }\end{array}$} & \multicolumn{3}{|c|}{ Metastasis } \\
\hline & & & & & liver & lung & $\begin{array}{l}\text { lymph } \\
\text { node }\end{array}$ \\
\hline \multirow{2}{*}{1} & $8 \times 6$ & 0.2 & - & - & - & - & - \\
\hline & $7 \times 6$ & 0.2 & - & - & - & - & - \\
\hline \multirow{2}{*}{2} & $20 \times 19$ & 0.8 & + & - & - & - & - \\
\hline & $23 \times 20$ & 1.4 & + & - & - & - & - \\
\hline \multirow{2}{*}{3} & $26 \times 25$ & 3.2 & + & + & - & $t^{a}$ & - \\
\hline & $26 \times 25$ & 3.8 & + & + & - & + & $t^{c}$ \\
\hline \multirow{2}{*}{4} & $33 \times 27$ & 3.8 & + & + & + & $H^{b}$ & + \\
\hline & $33 \times 28$ & 4.0 & + & + & + & + & + \\
\hline \multirow{2}{*}{5} & $45 \times 30$ & 7.6 & + & + & + & H & $H^{d}$ \\
\hline & $50 \times 45$ & 9.2 & + & + & - & H & H \\
\hline 8 & $-f$ & $-f$ & + & + & + & $\mathrm{H}^{\mathrm{c}}$ & $\mathrm{m}^{\mathrm{e}}$ \\
\hline
\end{tabular}

a, miliary size. b, rice-grain size. c, pea size. d, little finger's headsize. e, thumb's head size. $f$, too large to measure. 
を゙移植した後， 1 週間ごとに 2 頭づつ屠殺して腫瘍の大 きさと転移の様子を観察した結果で，11頭湩瘍の生着 を認めた。腫瘍の大きさは 1 週後には約 $10 \mathrm{~mm} \times 10 \mathrm{~mm}$ に成長し, 以後直線的に増大して, 3 週目には約 $26 \mathrm{~mm} \times$ $25 \mathrm{~mm}$ となり，その後の增殖は緩慢になった(Fig. 2). しかし，8週を経過する之膀胱腫瘍は隣接臓器き腹壁に 浸潤し，腫場の大きさを測定するのが不可能な惒汇增六 した。腫瑒の形態は 1 週目には膀胱壁の粘膜下に結節状 腫瘤を形成していたが (Fig. 3)，2 週目には膀胱粘膜 を破って膀胱粘膜面に潰瘍を形成するようになり（Fig， 4)，3 週目には潰瘍の中央に壊死による陥山と乞れを囲 む結節状隆起を認めた。腫㿑の増殖は主に平面的に拡が り, 各時期の腫瘍面積を長径 $\times$ 短径で求めて, 腫瘍重量 との関係をみると活ぼ相関していた（r=0.964, Fig。 5).

転移の様子を肺，肝，括よび傍総腸骨動脈りンパ節の

Fig. 2 Growth curve of bladder tumor in rabbits.

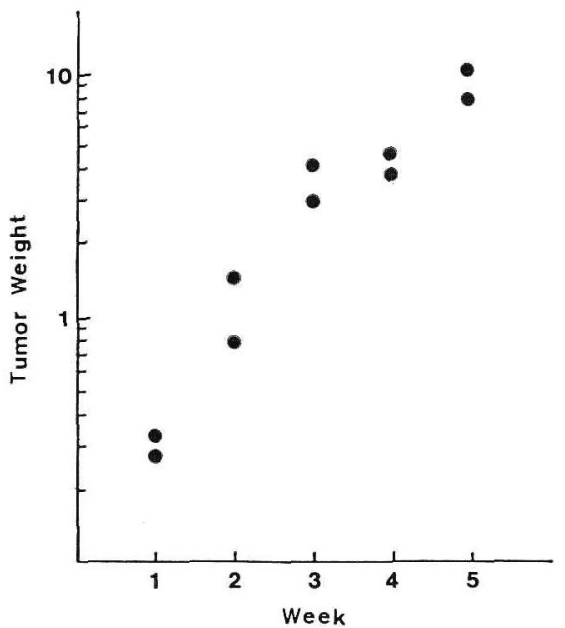

Fig. 3 One week after inoculation. Tumor growth restricted in submucosa to muscle layer.

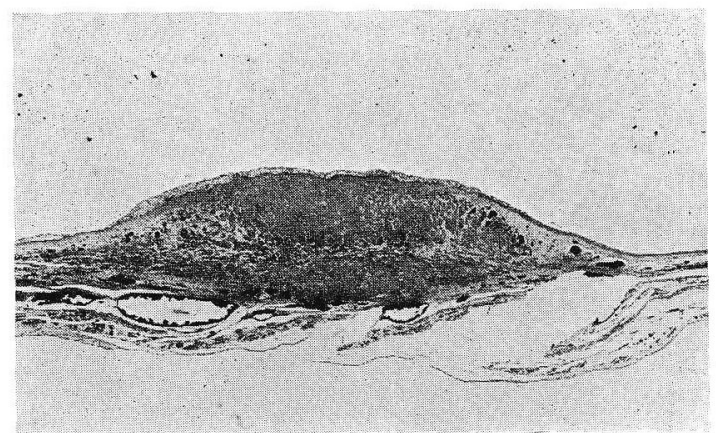

Fig. 4 Two weeks after inoculation. Mucosal layer was invaded by tumor growth showing erosion.

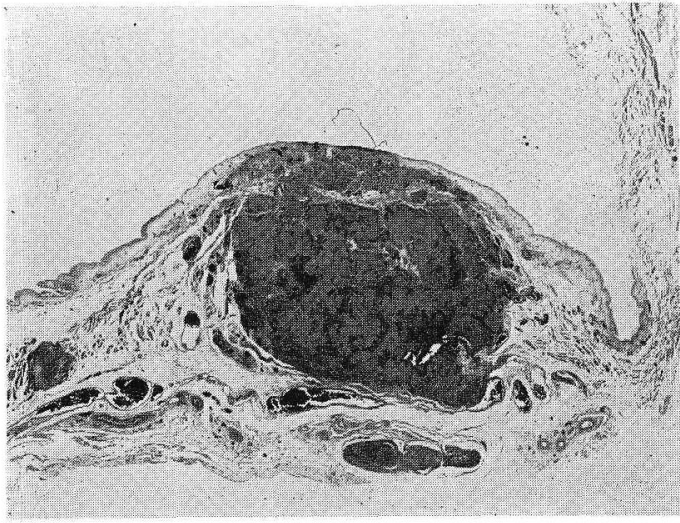

Fig. 5 Correlation between tumor weight and size. Tumor size was caluculated using the formula, length $\times$ width $=\mathrm{mm}^{2}$.

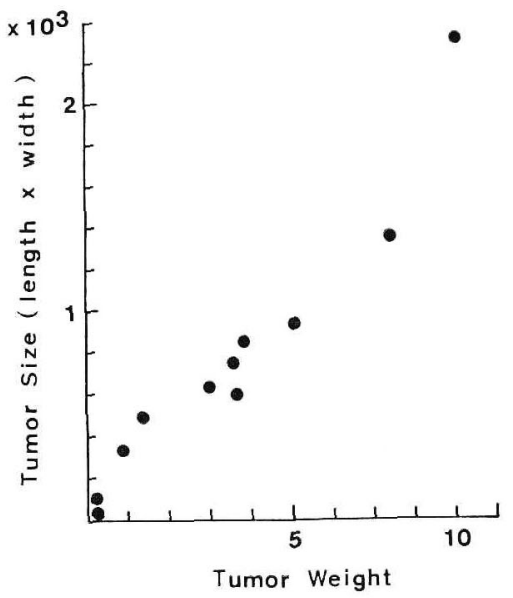

3 力所で検索すると，肺とリンパ節には 3 週目より肉 眼的転移が認められ，以後時間の経過とともに段階的に 増大寸るのが観察された。 8 週目には両肺野は小豆大の 無数の転移巣で埋めつくされ，リンパ節は小指頭大〜拇 指頭大に腫大していた。それに反して畈には4 週目に米 粒大の転移巣が数個認められたものの，8週を経過して も増大する傾向はなかつた (Table 2). 以上の転移様式 は家鬼の体重をよく反映して招り，細胞移植後 2 週目， 3 週目と順調に体重が増加したのが 4 週目には横ばいと なり，5週目からは体重が減少し始めた（Fig. 6).

4. 病理組織像：腫瘍組織は血管に乏しい薄い結合組 織にとり囲まれて果状をなして扣り，その中に円形の核 
を有する多形性の上皮性腫富細胞が密集し，リンパ球と 好酸球を主体とする炎症性細胞浸潤が認められた（Fig. 7).腫瘍細胞内の核の大きさは核沟等で，いくつかの 核には分裂が認められ，核クロマチンも明膫に識別でさ た、リンパ節（Fig，8）抌よび肺（Fig，9）には，結節 状の転移巢が散在し，とくに肺ではリンパ管内に腫瘍が 塞栓状に増殖している所見を得た (Fig. 10).

Fig. 6 Weight of rabbits after inoculation of $\mathrm{V}_{2}$ carcinoma into the urinary bladder. Average weight of three rabbits (Mean $\pm S, E$.).

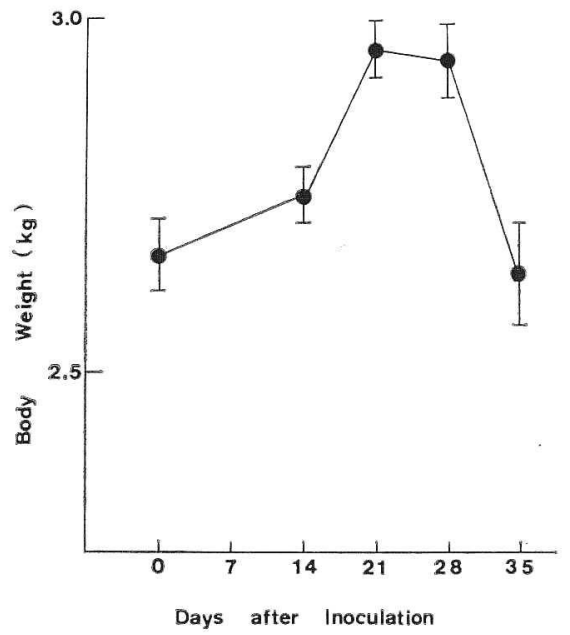

Fig. $7 V_{2}$ carcinoma transplanted into urinaly bladder of rabbits. Inoculated tumor cells growing solid sheets or nests with thin septal fibrous stroma. Lymphocytic infiltration intermingling in the stroma and relatively prominent mitotic figures are seen $(\times 100$, HE stain).

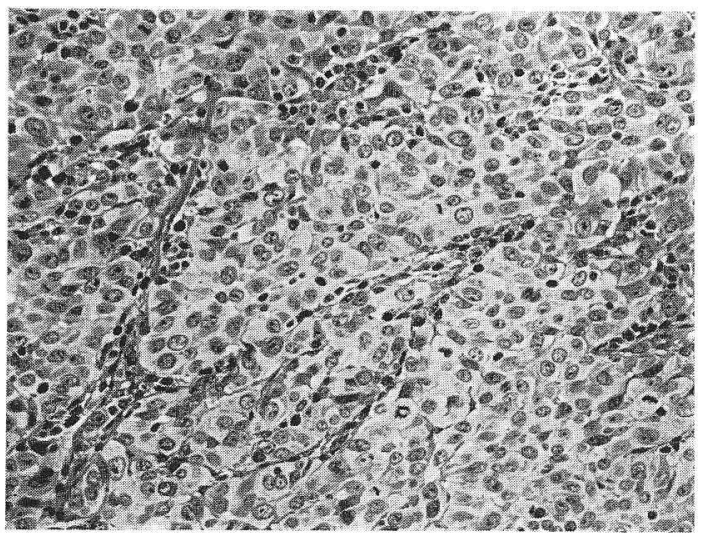

Fig. 8 Multiple metastasis nodules in the lung 4 weeks after inoculation $(\times 100, \mathrm{HE}$ stain $)$.

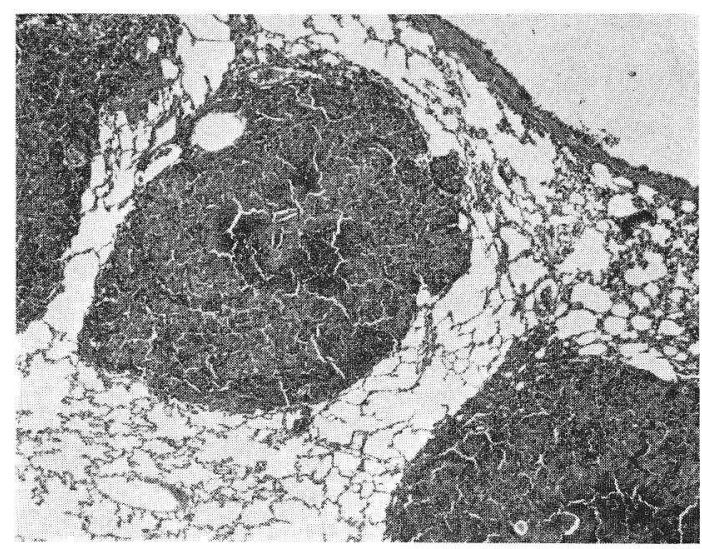

Fig. 9 Metastatic involvement of the lymph node 3 weeks after inoculation ( $\times 100, \mathrm{HE}$ stain).

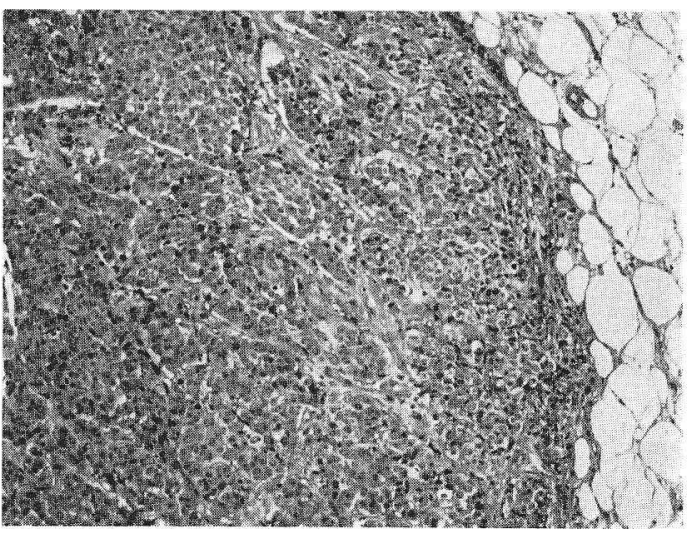

Fig. 10 Perivascular Iymphatic invasion of the lung resembling lymphangitic carcinomstosis.

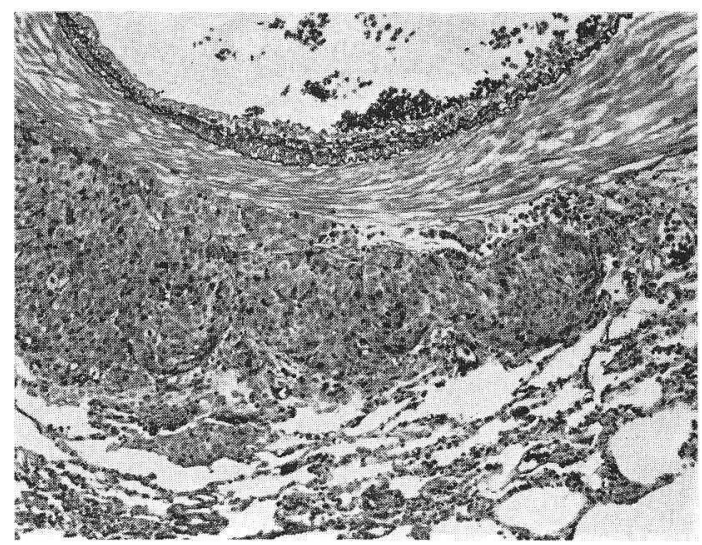


膀胱腫瘍の実験モデルとして最も一般的なものはラッ トに $\mathrm{BBN}^{7)}$ や $\mathrm{FANFT}^{8)}$ などの化学発癌物質を投与して 作成したもので，これらを用いた移植腫瘍実験系も城告 されている9 . しかし，ラットの膀胱腫瘍モデルを膀胱 玅の局所治療法の実験モデルにするには膀胱そのものが あまりに小さく，局所操作が極めて困難である。そのた め現在のところラットを用いた膀胱癌の局所治療法の央 験モデルとしては抗癌剤の膀胱内注入法に関する報告が 散見されるにすぎない(8)99.

その点, 膀胱の操作が容易な家鬼に膀胱腫瘍を作るこ とが出来れば申し分ないが，家鬼の膀胼腫瘍に関しては 自然発生癌の報告はない，化学登癌物質による方法も再 現性に乏しく，不確実で腫瘍発生までに時間がかかりす ぎて実用には程遠い状態である(10)11)。そこで著者らは， 家鬼の同種移植腫瘍 $\left(V_{2}\right.$ carcinoma) に着目し，これを 膀胱に移植, 生着させて膀胱腫瘍を作り, 膀胱癌の局 所化学療法に関するモデル串験としての可能性を示し た

今回は， $V_{2}$ carcinoma を用いた家鬼の移植膀胱腫瘍 に関する基礎的実験を系統的に行なつた。その結果，2 $\times 10^{4}$ 個以上の腫瘳細胞を家鬼の膀胱壁に移植してから 1 週間でほぼ100\%に近い確率で膀胱腫湯を作ることが でき，しかも各実験系により腫瘍の大きさや転移の発現 がほぼ一定した再現性のある移植膀腃腫瘍モデルを確立。 することができた，腫瘍の大きさは長径×短径で表わす ことにより腫瘍重量とよく相関することが示され, 各種 の治療効果を判定するのに非常に好都合なモデルと思わ れた。また生着した腫瘍の大きさは移植細胞数と密接な 関係があり，練胞数を調整することによつて目的にかな つた成長速度の実験系を作ることも可能である。

腫湟の転移は 3 週目に肺と傍総腸骨動脈リンハ節に認 められた。これらの転移巣は時間の経過とともに增大 し，8週目になると両肺野は小豆大の腫瘍で埋めつくさ れた。肺転移巣の組織学的所見では, 主にリンパ管内に 腫瘍細胞が集中しているのが認められた。しかし肝転移 は極めてわずかで，時間の経過とともに増大する傾向も なかつた．以上のことから本実験モデルの転移形式は， リンパ行性に肺に至ると考えられ，膀胱癌のリンパ節転 移に関する実験モデルとしての有用性も示唆された。

最近, Harzmann ら女家鬼の陰のらに発生した Brown Pearce carcinoma を用いた移植膀胱腫瘍の実験モデル を報告した ${ }^{11)}$ 。しかし，著者らが $V_{2}$ carcinoma を用い
て作成した奏験モデルとの間には幾つかの相違点を指摘 寸ることができる。その1つはHarzmann らのモデル で、膀脱腫瘍を膀胱腙内に生着させるにあたつて、膀腅 の粘膜に蛍傷を作るか，粘膜下層に選択的に細胞を泎人 寸る必要がある点である，著者らのモデルでは膀脱譬い の細胞移植は全く無選扒かつ無雑作に行なわれたが，絬 果的には再現性のある均一な腫瘍を膀胱に生着させるこ 上ができた，腫湯は移植 1 週後に粘膜卜に結節状に生着 し，2 週後には粘膜百に溃瘍を形成しながら膀胱腔内に 突出する浸潤性発育を示した。この点, 本法は Harzmann らのモデルに比べて移植操作がはるかに簡単で，垱 胱粘膜に対する不必要な浸襲もなく，より然な形で䨤! 揘を生着させ得る利点がある。もう一つの大きな相違焏 は, Harzmann らの実験モデルでは腫瘍の転移形式がIIIL 行性で主に朋藏が浸されるのに対し，著者らのモデルは リンパ行性に肺に転移する点である。この陃者の転移形 式のちがいは，今後の実験モデルの選定にあたつて興味 ある問題を提起しそらである。

以トの点から本実験モデルは短期間に，簢単な操作:で 家鬼の膀脱に再現性のある悪性腫瘳を作ることができ, 化学発癌等による事験系に比べて極めて経済的とい兄 る. $V_{2}$ carcinoma を用いた移植腫愓は組織型が本来の 肪胼腫陽である移行上支嘻と異なる点を除けば，増殖形 式や転移様式は膀胱原発の悪性腫腫瘍と同等の条件を十 分に渾足しているため, 膀胱癌の治療とくに局所治療に 関する実験モデルとして抗腫瘍効果の判定や抗腫瘍機序 の解明など幅広い伦用が期待される。

\section{結 語}

家鬼移植腫瘍（ $\mathrm{V}_{2}$ carcinoma）を用いた膀脂癌の実験 モデルを確立寺るため, 基礎的実験を行ない以下の結果 龙得た。

I. $2 \times 10^{4}$ 個以上の $\mathrm{V}_{2}$ 腫湯細胞を移植した 81 頭中， 78頙に腫場の生着がみられ，生着率は96\%であつた。腫 倠はすべて膀脱腔内に突出し, 齐车験群でほ注均等な大 きさの腫瘍が得られた。

2. 腫瘍はまず粘膜下層に結節状に生着し，その後粘 膜面に潰瘍を形成して中心壞死を伴いながら増殖する形 をとつた。

3. 転移経路は膀胱より傍総腸骨動脈リンパ節を経て 肺に至るリンパ行性転移が主体で，転移巣の増大ととも に一部肝への血行性転移も認められた。

4. 本実験モデルには手技が簡便なこと, 腫瘍生着率 が高く再現性に富さこと，ならびに実験期間が短いこ々 
等の利点が指摘された。

5. 本実験モデルは組織学的に自然発生膀胱癌とは異 なるが，增殖形態，成育速度および転移様式が悪性腫場 としての条件を満しており, 膀胱癌治療に関する基礎的 研究に幅広い応用が期待できる.

（本論文の要旨恃第68回日本泌尿器科学会総会に求い て発表した。また, 本研究の一部は厚生省がん研究助成 金（53〜19）和よび文部省科学研究費（56570537）に上 り行なつた。）

\section{文献}

1) Nevin, J.E. and Hoffman, A.A.: Use of arterial infusion of 5-fluorouracil either alone $o_{i}^{*}$ in combination with supervoltage radiation as a treatment for carcinoma of the prostate and bladder. Am. J. Surgery, 130, 544$549,1975$.

2）加藤哲郎, 根本良介：泌尿器悪性腫瘍に対する 化学塞栓療法. 臨床外科, 35, 379-386, 1980.

3) Kato, T., Nemoto, R., Nishimoto, T., Kumagai, I. and Miura, K.: Chemosensitivity of human bladder cancer cells in long-term culture and clinical responses to the selected anticancer drugs. Cancer, 44, 58-63, 1979.

4) 広瀬欽次郎, 加納勝利, 瀬戸輝一：膀脱腫韵に 対する水圧療法飞ついて。第 1 報, 日泌尿会 誌, 64, 324-337, 1973.

5) 岸本 孝, 岡田清己, 滰本至得, 北島清彰, 熊 谷振作, 新井律夫, 中村洋三, 広田米造, 清水 伸一, 森田博人: 膀胱腫瘍飞対する温水療法 (Hyperthermic Treatment) の研究. 第 1 報. 臨 床的経験。日泌尿会誌，66，485-492，1975.

6) Kidd, J.G. and Rous, P.: A trarsplantable rabbit carcinoma originating in a virus-induced papilloma and containing the virus in masked or altered form. J. Exper. Med., 71, 813-
838, 1940.

7) 野田益弘, 橋本嘉幸 : N-butyl-N-butanol (4) nitrasamine およびそのアセチル体による近交 系 $\mathrm{ACI} / \mathrm{N}$ ラット膀胱腫瘍の発生と発生腫場の 移植性について。目泌尿会誌，64，397-401， 1973.

8) Pontes, J.E., Izbicki, R., Silberberg, B., Baker, L. and Pierce, J.M.: The effects of topical instillation of adriamycin in bladder tumors of rats fed with FANT. Invest. Urol., 15, 278279, 1978.

9）横田武彦, 香川 征: 近交系 ACT/N ラット移 植膀腅腫瘍ならびに組織培養にお比る化学療法 の検討。日泌尿会誌， 66, 249-253，1975.

10）上領頼啓：各種抗癌剤の膀胱癌再発予防に関す る実験的研究. 第27回 日本化学療法学会総会, 抄録集, 57, 1979 .

11) Soloway, M.S.: Intravesical and systemic chemotherapy of murine bladder cancer. Cancer Res., 37, 2918-2929, 1977.

12) Cohen, A.E., Weisburger, E.K., Weisburger, J.H., Ward, J.M. and Putman, C.L.: Cystoscopy of chemically induced bladder neoplasms in rabbits adninistered the carcinogen dibutylnitrosamine. Invest. Urol., 12, 262266, 1975.

13) Harzmann, R., Gericke, D., Bichiler, K.H. and Altenar, E.: A transplantable tumor of the urinary bladder in rabbits. Invest. Urol., 17, 181-815, 1979.

14) Kato, T., Nemoto, R., Mori, H., Unno, K., Goto, A., Harada, M. and Homma, M.: Preparation and characterization of ferromagnetic mitomycin $\mathrm{C}$ microcapsules as a mean of magnetic control of anticancer drugs. Proc. Japan Acad., 55, 470-475, 1979.

(1981年1月16日受付) 